EPJ Web of Conferences 24, 03001 (2012)

DOI: $10.1051 /$ epjconf/20122403001

(c) Owned by the authors, published by EDP Sciences - SIF, 2012

\title{
Radiochemical analysis of waters and mud of Euganean spas (Padua)
}

\author{
C. Cantaluppi*, A. Fasson, F. Ceccotto, A. Cianchi \\ and S. Degetto
}

CNR - Institute of Inorganic Chemistry and Surfaces - C.so Stati Uniti 4 35127 Padova, Italy

\begin{abstract}
The area around the Euganean Hills (North-East Italy) is concerned with thermal phenomena known and used for therapeutic purposes since ancient times. The thermal waters collected in this area have taken up a natural radionuclides content due to the leaching of hot and permeable deep rocks, with which they come into contact, before their rising to the surface. During the "maturation" process of the mud used for treatment purposes, the thermal waters make happen a complex series of biochemical changes and release a series of chemical species to the mud, resulting, in particular, in an enrichment phenomenon for some radionuclides. In this work, the first radiochemical analysis extended to all the Euganean Thermal District is reported. In particular, chemical analyses of mud, as well as radiochemical analyses of both mud and waters were performed; the enrichment of the radioisotopes in mud used for treatments was also documented. The results show that the ${ }^{226} \mathrm{Ra}$ content in mud, during the "maturation" process, presents an enrichment even of one order of magnitude with respect to the value found in the unprocessed mud. Furthermore, in the same thermal waters, high concentrations of "unsupported" ${ }^{222} \mathrm{Rn}$ have been found, which have shown to be not completely negligible both for people under treatment and particularly for spa workers.
\end{abstract}

${ }^{*}$ E-mail: chiara.cantaluppi@icis.cnr.it

This is an Open Access article distributed under the terms of the Creative Commons Attribution License 2.0, which permits unrestricted use, distribution, and reproduction in any medium, provided the original work is properly cited. 


\section{Introduction}

The Euganean Hills are located in the Venetian Plain, in isolated position with respect to other hills or mountains; their origin is pseudo-volcanic. The thermal activity, which characterizes their eastern side, is known since prehistoric times (some less important thermal activity is also present on the western hills side). The thermal phenomenon is merely generated by the geothermal gradient, totally independent from the original volcanic activity, which ended about 30 million years ago. The Euganean thermal water comes from the "Piccole Dolomiti" (High North of Vicenza district) where meteoric precipitations deeply seep into ground until they reach the deep pre-Permian basement, impermeable, where waters warm up. During the contact with the water some mineral components are leached out (among them also radioactive elements, i.e. $\mathrm{U}, \mathrm{Th}$ and their decay products). The deep waters finally meet the geological structure of the Euganean Hills, a sort of barrier that, nevertheless, helps the rising of water to the surface, throughout a system of fractured rocks. The region of water seepage was found to be the "Piccole Dolomiti" on the basis of the isotopic composition of Oxygen $\left({ }^{16} \mathrm{O} /{ }^{18} \mathrm{O}\right)$; furthermore the amount of ${ }^{3} \mathrm{H}$ decay, with respect to its activity at the origin, shows that water could take not less than 50 years to run the entire path $[1,2]$. The geographical distribution of the thermal springs and their field of temperature were recently revisited [3].

The Euganean Thermal District includes the towns of Abano, Montegrotto, Battaglia and Galzignano. At present, there are more than 120 spas in Abano and Montegrotto; some others are present in the bordering towns.

Since many years the natural rising of thermal water has not been observed anymore; the hot waters are nowadays extracted by means of wells. These wells sometimes can be particularly deep (up to $1000 \mathrm{~m}$ ).

The mud used in spas (after a special "maturation" treatment, see below) mainly comes from a small Euganean lake sited near Arquà Petrarca and, in a smaller amount, from the tiny lake of Lispida, between Battaglia and Monselice.

The fresh mud, stored in concrete basins, is put into contact with the hot hyperthermal water $\left(60^{\circ} \mathrm{C} \div 85^{\circ} \mathrm{C}\right)$, for a variable period, still depending from practitioner and spa traditions (sometimes, but not often, up to 1-2 years). In this period of time the mud undergoes significant changes due to the growing of specific thermophile microorganisms; the accumulation of their metabolites confers particular therapeutic properties to the mud that, in this way, become fully "mature" [4]. The maturation is a very complex process, which includes the growth of microorganisms (bacteria and 
protozoa), but also micro algae, as well as the accumulation of many organic chemical species and trace elements. The mature mud is then used for the various therapeutic treatments, through cutaneous applications on patients.

The exhausted thermal mud is usually recycled in an appropriate treatment. The duration of the regeneration process mainly depends on the spa tradition and can take up to 1-2 years. The process needs to be properly monitored and, almost certainly, can be largely reduced. In fact, after only two months the formation of powerful anti-inflammatory products has already been reported $[5,6]$.

Thermal waters have many other therapeutic applications: aerosol therapy, hydro-massage, bath, sauna and other similar therapies.

The mud and thermal water radioactivity is known since the early years of the last century, but some investigations have been also performed in more recent times [7-11]; the presence of both ${ }^{238} \mathrm{U}$ and ${ }^{232} \mathrm{Th}$ series is now quite well established (some doubt was expressed by [10] about the presence of the ${ }^{232} \mathrm{Th}$ series). Owing to the limited number of hot thermal waters studied in the past, there was the need of a wider investigation extended to a larger and representative number of spas.

This work deals with a radiochemical analysis extended for the first time to all Euganean Thermal District. In particular, chemical analyses of mud, as well as radiochemical analyses of both mud and waters were performed; the enrichment of the radioisotopes in mud used for treatments was also documented.

\section{Materials and methods}

\section{Sampling}

The present study concerns water and mud samples coming from 25 spas located in the areas of Abano and Montegrotto towns; the same sites were considered in a previous research [12], even though limited to chemical analyses of the mud. The present study, carried out on many sampling sites evenly distributed over the district, is likely to be representative of the entire spas population.

For the sake of privacy the spas company names are not recognizable; the various sites have been defined through a progressive number, $\mathrm{C} 1 \div \mathrm{C} 25$; both water and mud samples were taken in each spa.

Water samples were collected in $0.5 \mathrm{~L}$ Teflon ${ }^{\circledR}$ bottles and immediately sealed for gamma spectrometry, but in $10 \mathrm{~L}$ high density poly ethylene (HDPE) canisters for all the other analyses. 
A second sampling, with the aim to only analyze the radionuclides ${ }^{226} \mathrm{Ra}$ and ${ }^{222} \mathrm{Rn}$ in water, was carried out six months later. Water samples were collected, wherever possible, directly at the well or at the input pipe of the first mud tank. Mud samples were collected directly from the tanks in which they were deposited, after their maturation period.

\section{Radionuclides determination}

The determination of the radionuclides activity concentration in the water and mud samples was made through High Resolution Gamma Ray Spectrometry with high purity germanium detectors; the main characteristics of these detectors are reported in [13]. For spectral analysis the Genie ${ }^{\circledR}$ software (Canberra) was used.

Each mud sample was analyzed "as it is" (after homogenization), without any pre-treatment, in a $1 \mathrm{~L}$ Marinelli beaker for the determination of the " $4 \mathrm{n}$ " $\left({ }^{232} \mathrm{Th}\right)$ and " $4 \mathrm{n}+2$ " $\left({ }^{238} \mathrm{U}\right)$ radioactive series, ${ }^{40} \mathrm{~K}$ and eventually ${ }^{137} \mathrm{Cs}$, whereas in a $250 \mathrm{~mL}$ sealed Al bottle for the determination of ${ }^{226} \mathrm{Ra}$ through the ${ }^{222} \mathrm{Rn}$ daughters. Likewise, the water samples were analyzed in $0.5 \mathrm{~L}$ sealed Teflon ${ }^{\circledR}$ bottles for the determination of ${ }^{226} \mathrm{Ra}$ through ${ }^{222} \mathrm{Rn}$ daughters.

"Supported" Radon is the one in equilibrium with the Radium effectively present in the sample; the remaining is defined as "unsupported"; for the most part, in these samples, Radon exceeds the "supported" part.

Sealed bottles were measured about 3-4 hours after collection, to ensure equilibrium between ${ }^{222} \mathrm{Rn}$ and short-lived daughters $\left({ }^{214} \mathrm{~Pb}\right.$ and $\left.{ }^{214} \mathrm{Bi}\right)$ before measurement; the total ${ }^{222} \mathrm{Rn}$ activity was measured through the $609 \mathrm{keV}$ photon emission of ${ }^{214} \mathrm{Bi}$ and the $352 \mathrm{keV}$ photon emission of ${ }^{214} \mathrm{~Pb}$. A second measurement was made after about 30-40 days, to ensure radioactive equilibrium between ${ }^{226} \mathrm{Ra}$ and ${ }^{222} \mathrm{Rn}$ (determination of "supported" ${ }^{222} \mathrm{Rn}$ ); the "unsupported" ${ }^{222} \mathrm{Rn}$ fraction is then calculated by difference.

The total ${ }^{226} \mathrm{Ra}$ was measured in the unfiltered water, whereas the soluble fraction was measured after filtration on a $0.45 \mu \mathrm{m}$ cellulose filter.

The efficiency calibrations for the various sample geometries used for the measurements (Marinelli beakers, bottle containers) were obtained through certified multigamma standard solutions (QCY48, and QCYB40 from Amersham). The uncertainty of all the measurements reported in this work is better than $10 \%$ (at 95\% confidence). The correction for self-attenuation of gamma rays in the mud samples, with respect to the calibration solution, was done through the method reported in [14]; the efficiency of the measuring system is periodically checked through inter-laboratory and 
inter-calibration tests performed by the National Physics Laboratory in Teddington (UK).

\section{Elemental analysis}

Elemental analyses were carried out on dry samples reduced to tablet form, with an energy dispersive, polarised X-ray fluorescence spectrometer (EDP$\mathrm{XRF}$ ). Each sample was prepared by finely pulverising the dried sample in a vibrating mill (equipped with a zirconia grinding system) and mixing it with Wachs-C 80004005 Mikropulver, a paraffinic wax which helps to reduce samples to tablets through pressure. The instrument was calibrated with a series of certified reference materials (CRM) reported in [15]. The analytical precision, measured at $95 \%$ confidence, for major, minor and trace elements $(\mathrm{Pb}, \mathrm{Cd}, \mathrm{As}, \mathrm{Zn}, \mathrm{Cu}, \mathrm{Ni}$ and $\mathrm{Mn}$ ), was routinely between $4 \%$ to $6 \%$, and about $10 \%$ for Cr. The average analytical standard uncertainties observed with the reported certified materials were always $<10 \%$ for major, minor and trace elements.

\section{Results and discussion}

\section{Mud analysis}

The radionuclide content of mud in use at the 25 spas is given in table 1 , whereas, for sake of brevity, the full data set of the whole elemental composition is not reported here, see [13]. The radionuclide content of a fresh mud sample from the small lake near Arquà Petrarca is reported in table 2. It is worth noting that ${ }^{232} \mathrm{Th}$ cannot be measured directly through Gamma Spectrometry (unless the radioactive equilibrium with ${ }^{228} \mathrm{Ac}$ is guaranteed); it was calculated from the mass concentration determined through $\mathrm{X}$-ray fluorescence analysis with EDP-XRF.

The radionuclides content in spa mud samples has generally a relatively higher activity concentration in comparison with the starting fresh mud of the Arquà Petrarca lake; this is particularly evident for the ${ }^{226} \mathrm{Ra}$ content. As far as the elemental composition is concerned, large similarities among all the samples can be noted [13]; second order differences, in the major elements content, could be possibly expected by the use, in some spas, of a quantity of mud coming from the Lispida lake. However, Cluster Analysis on sample cases clearly shows the outstanding composition of the C12 and C25 mud samples (see fig. 1); in particular, between major constituents, higher values for $\mathrm{Al}, \mathrm{Ti}, \mathrm{Fe}$, but minor for $\mathrm{Mg}$ and $\mathrm{Ca}$ can be observed. 
Table 1: Radionuclide content in mud samples from 25 spas (data in $\mathrm{Bq} \mathrm{kg}^{-1}$, samples dried at $110^{\circ} \mathrm{C}$ ).

\begin{tabular}{|c|c|c|c|c|c|}
\hline Sample & $\begin{array}{c}{ }^{226} \mathrm{Ra} \\
\left(\mathrm{Bq} \mathrm{kg}^{-1}\right)\end{array}$ & $\begin{array}{c}{ }^{228} \mathrm{Ra}^{\left({ }^{a}\right)} \\
\left(\mathrm{Bq} \mathrm{kg}^{-1}\right)\end{array}$ & $\begin{array}{c}{ }^{40} \mathrm{~K} \\
\left(\mathrm{~Bq} \mathrm{~kg}^{-1}\right)\end{array}$ & $\begin{array}{c}{ }^{210} \mathrm{~Pb} \\
\left(\mathrm{~Bq} \mathrm{~kg}^{-1}\right)\end{array}$ & $\begin{array}{c}{ }^{232} \mathrm{Th}^{(b)} \\
\left(\mathrm{Bq} \mathrm{kg}^{-1}\right)\end{array}$ \\
\hline C 1 & 215 & 114 & 437 & 147 & 34 \\
\hline C 2 & 97 & 52 & 350 & 47 & 30 \\
\hline C 3 & 227 & 113 & 503 & 134 & 41 \\
\hline C 4 & 116 & 55 & 459 & 94 & 37 \\
\hline C 5 & 168 & 87 & 419 & 96 & 35 \\
\hline C 6 & 253 & 63 & 446 & 157 & 35 \\
\hline C 7 & 221 & 63 & 393 & 71 & 30 \\
\hline C 8 & 414 & 38 & 385 & 171 & 29 \\
\hline C 9 & 209 & 54 & 422 & 112 & 39 \\
\hline C 10 & 278 & 51 & 419 & 120 & 37 \\
\hline C 11 & 305 & 91 & 495 & 286 & 40 \\
\hline C 12 & 35 & 56 & 481 & 27 & 44 \\
\hline C 13 & 391 & 29 & 436 & 206 & 35 \\
\hline C 14 & 145 & 87 & 427 & 101 & 35 \\
\hline C 15 & 396 & 56 & 367 & 107 & 31 \\
\hline C 16 & 547 & 48 & 463 & 221 & 35 \\
\hline C 17 & 553 & 30 & 390 & 177 & 32 \\
\hline C 18 & 466 & 41 & 414 & 134 & 33 \\
\hline C 19 & 266 & 67 & 419 & 143 & 34 \\
\hline C 20 & 229 & 68 & 358 & 107 & 30 \\
\hline C 21 & 412 & 68 & 363 & 150 & 30 \\
\hline C 22 & 287 & 34 & 412 & 142 & 37 \\
\hline C 23 & 462 & 38 & 441 & 131 & 35 \\
\hline C 24 & 264 & 73 & 420 & 142 & 35 \\
\hline C 25 & 187 & 102 & 556 & 56 & 44 \\
\hline Mean & 286 & 63 & 427 & 131 & 35 \\
\hline Std. dev. & 138 & 24 & 48 & 56 & 4 \\
\hline Min. & 35 & 29 & 350 & 27 & 29 \\
\hline Max & 553 & 114 & 556 & 286 & 44 \\
\hline
\end{tabular}


Table 2: Radionuclide content in mud samples from the lake near Arquà Petrarca (data in $\mathrm{Bq} \mathrm{kg}^{-1}$, samples dried at $110^{\circ} \mathrm{C}$ ).

\begin{tabular}{lcccccc}
\hline Sample & $\begin{array}{c}{ }^{226} \mathrm{Ra} \\
\left(\mathrm{Bq} \mathrm{kg}^{-1}\right)\end{array}$ & $\begin{array}{c}\left.{ }^{228} \mathrm{Ra}^{(a}\right) \\
\left(\mathrm{Bq} \mathrm{kg}^{-1}\right)\end{array}$ & $\begin{array}{c}{ }^{40} \mathrm{~K} \\
\left(\mathrm{~Bq} \mathrm{~kg}^{-1}\right)\end{array}$ & $\begin{array}{c}{ }^{210} \mathrm{~Pb} \\
\left(\mathrm{~Bq} \mathrm{~kg}^{-1}\right)\end{array}$ & $\begin{array}{c}{ }^{232} \mathrm{Th}^{(b)} \\
\left(\mathrm{Bq} \mathrm{kg}^{-1}\right)\end{array}$ & $\begin{array}{c}{ }^{137} \mathrm{Cs} \\
\left(\mathrm{Bq} \mathrm{kg}^{-1}\right)\end{array}$ \\
\hline Arquà P. & 61 & 53 & 432 & 127 & 34 & 3.01 \\
\hline${ }^{\left({ }^{a}\right)}{ }^{228} \mathrm{Ra}$ was measured from ${ }^{228} \mathrm{Ac}$ content measured through gamma spectrometry. \\
${ }^{(b)}{ }^{232} \mathrm{Th}$ was calculated from total Th content measured through EDP-XRF.
\end{tabular}

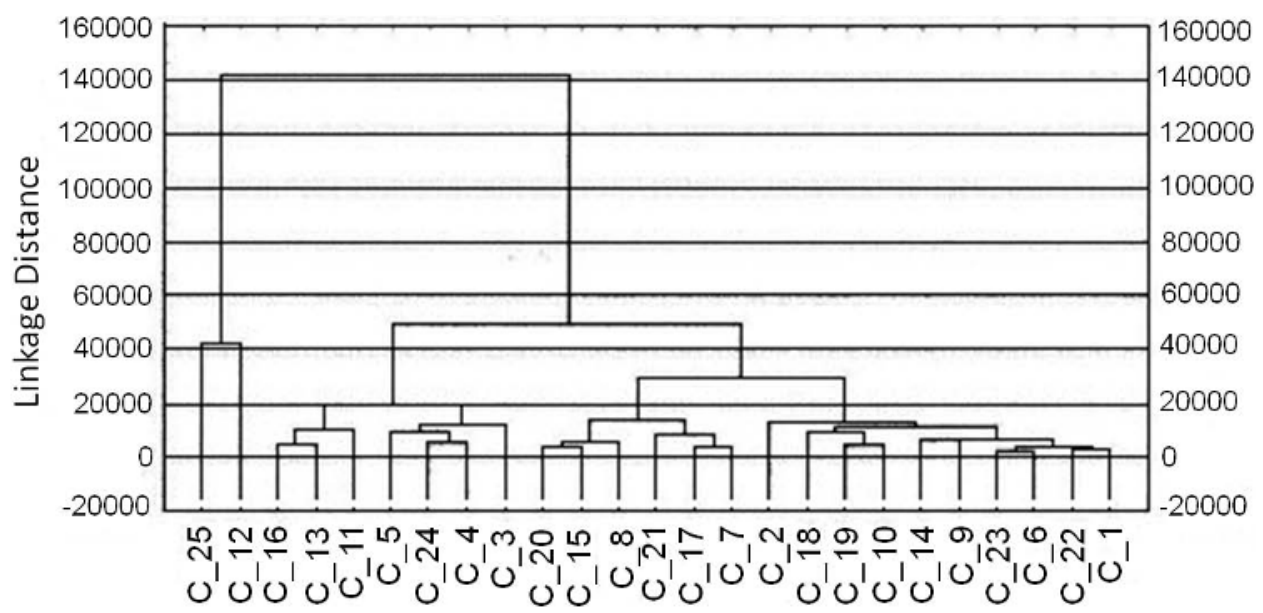

Figure 1: Cluster analysis on samples cases for the 25 samples $\left(1^{\text {st }}\right.$ sampling campaign 2003).

This should be probably connected to the addition of materials unrelated to the usual unsophisticated mud composition (such as benthonite). During the previous mud sampling [12], only the spa corresponding to C25 showed unusual elemental composition (see fig. 2); the new ascertained case (C12) could be related to the increasing difficulty in getting fresh mud from natural sources.

Based on these considerations the anomalous samples C12 and C25 were not considered carrying out the statistical analysis of samples. The linear regression coefficients (reported in [13] for sake of brevity) between all elements and radionuclides display some relevant relationship as for instance: $\mathrm{Al} / \mathrm{Si} / \mathrm{Ti} / \mathrm{Ga}, \mathrm{Fe} / \mathrm{Ni}$ and $\mathrm{K} / \mathrm{Rb} /{ }^{232} \mathrm{Th}$. In addition, there is no connection between the two radioisotopes ${ }^{226} \mathrm{Ra}$ and ${ }^{228} \mathrm{Ra}$ due to their well-known different sources (decay products of ${ }^{238} \mathrm{U}$ and ${ }^{232} \mathrm{Th}$, respectively); see also the 


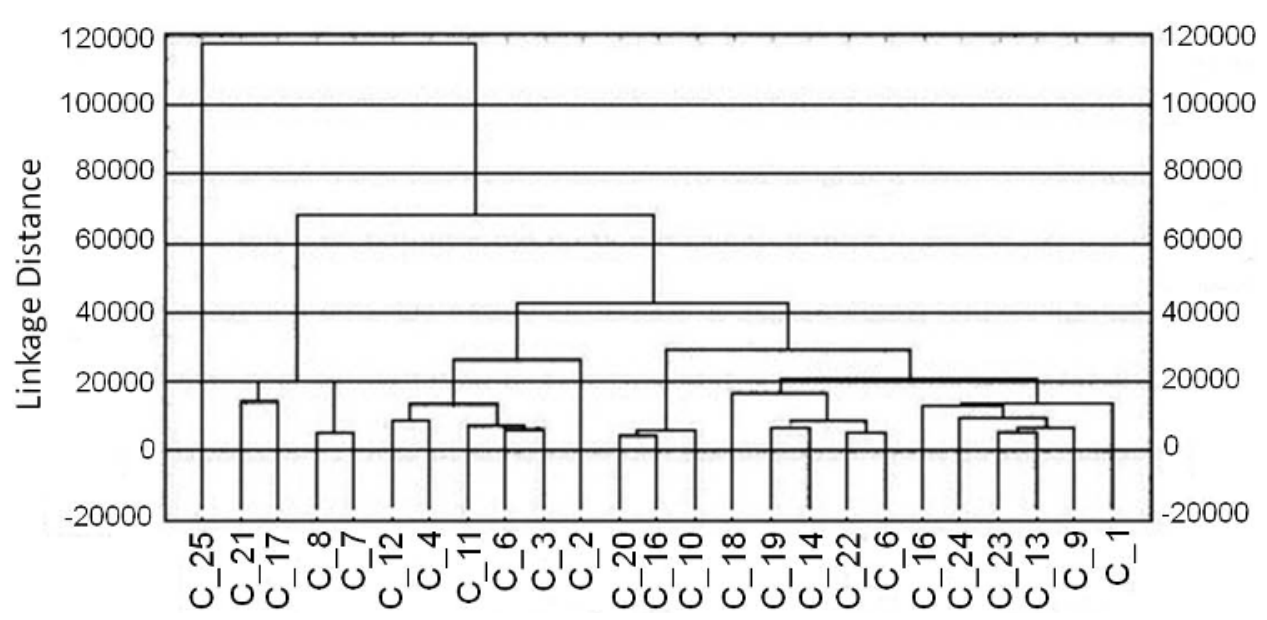

Figure 2: Cluster analysis on sample cases for the 25 samples of the previous sampling campaign (2001) [12].

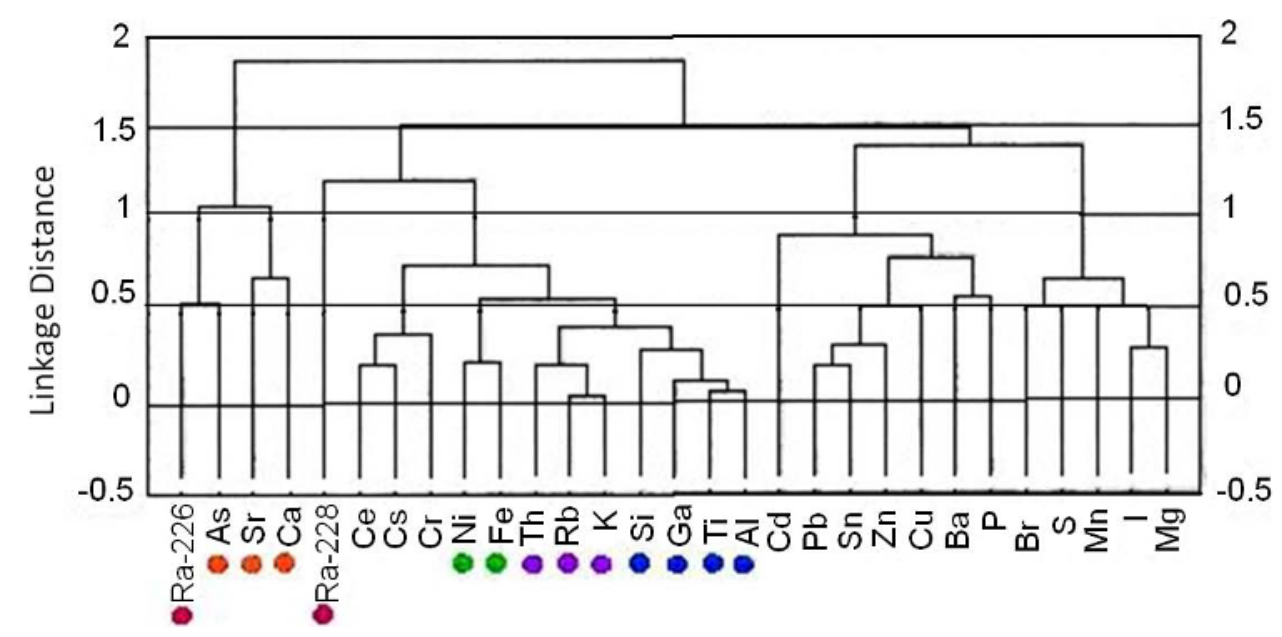

Figure 3: Cluster analysis on elemental composition for the 25 samples $\left(1^{\text {st }}\right.$ sampling campaign 2003). 
Table 3: Main statistical parameters of the 25 mud samples taken in 2003 in comparison with the samples taken in 2001 (data in $\mathrm{mg} \mathrm{kg}^{-1}$ ).

\begin{tabular}{|c|c|c|c|c|c|c|c|c|c|}
\hline \multicolumn{5}{|c|}{ Samples June 2003} & \multicolumn{5}{|c|}{ Samples June 2001} \\
\hline Elem & mean & $\min$ & $\max$ & std dev & Elem & mean & $\min$ & $\max$ & std dev \\
\hline $\mathrm{Mg}$ & 24977 & 14799 & 29727 & 3056 & $\mathrm{Mg}$ & 26745 & 18816 & 30516 & 2594 \\
\hline $\mathrm{Al}$ & 45921 & 36077 & 79317 & 10565 & $\mathrm{Al}$ & 42499 & 35141 & 71022 & 7371 \\
\hline $\mathrm{Si}$ & 183438 & 159455 & 239984 & 18874 & $\mathrm{Si}$ & 183323 & 153656 & 218867 & 14880 \\
\hline $\mathrm{P}$ & 638 & 249 & 949 & 147 & $\mathrm{P}$ & 720 & 524 & 1048 & 120 \\
\hline K & 13912 & 11602 & 18657 & 1614 & K & 13857 & 11290 & 18429 & 1763 \\
\hline $\mathrm{Ca}$ & 132679 & 44550 & 156461 & 23172 & $\mathrm{Ca}$ & 132613 & 76973 & 168596 & 18659 \\
\hline $\mathrm{Ti}$ & 2501 & 1812 & 4277 & 524 & $\mathrm{Ti}$ & 2474 & 2098 & 3537 & 332 \\
\hline $\mathrm{Cr}$ & 42 & 23 & 92 & 16 & $\mathrm{Cr}$ & 63 & 31 & 135 & 23 \\
\hline $\mathrm{Mn}$ & 830 & 573 & 1094 & 139 & Mn & 824 & 542 & 1162 & 167 \\
\hline $\mathrm{Fe}$ & 20252 & 10950 & 45439 & 6891 & $\mathrm{Fe}$ & 25085 & 17745 & 39593 & 5383 \\
\hline $\mathrm{Ni}$ & 26 & 10 & 73 & 13 & $\mathrm{Ni}$ & 30 & 20 & 68 & 12 \\
\hline $\mathrm{Cu}$ & 31 & 16 & 68 & 14 & $\mathrm{Cu}$ & 39 & 19 & 123 & 23 \\
\hline $\mathrm{Zn}$ & 117 & 55 & 233 & 44 & $\mathrm{Zn}$ & 144 & 71 & 313 & 61 \\
\hline $\mathrm{Rb}$ & 78 & 60 & 106 & 11 & $\mathrm{Rb}$ & 95 & 75 & 123 & 13 \\
\hline $\mathrm{Sr}$ & 426 & 339 & 488 & 35 & $\mathrm{Sr}$ & 538 & 451 & 625 & 43 \\
\hline $\mathrm{Ba}$ & 268 & 234 & 403 & 36 & $\mathrm{Ba}$ & 273 & 228 & 413 & 38 \\
\hline $\mathrm{Ce}$ & 47 & 39 & 68 & 7 & $\mathrm{Ce}$ & 73 & 62 & 95 & 9 \\
\hline $\mathrm{Pb}$ & 29 & 15 & 55 & 9 & $\mathrm{~Pb}$ & 19 & 0 & 45 & 12 \\
\hline Th & 9 & 7 & 11 & 1 & Th & 10 & 0 & 15 & 4 \\
\hline
\end{tabular}

Cluster Analysis reported in fig. 3. In table 3 the main statistical parameters for the 25 mud samples are reported in comparison with the previous 2001 sampling campaign.

The most significant remark, concerning the radionuclide content of thermal mud, is related to the increased ${ }^{226} \mathrm{Ra}$ concentration with respect to the fresh mud from the Arquà Petrarca lake.

The comparison with literature data $[10,11]$ is unfortunately limited to a small number of cases. However, the ${ }^{226} \mathrm{Ra}$ activity concentration, which is connected to the mud "story", is highly variable (in one case, [11], a ${ }^{226} \mathrm{Ra}$ activity concentration of $1208 \mathrm{~Bq} \mathrm{~kg}^{-1}$ was reported, which is above the limit of $1000 \mathrm{~Bq} \mathrm{~kg}^{-1}$, in the Italian radioprotection legislation [16]).

\section{Thermal water analyses}

The full table of physical data (temperature, $\mathrm{pH}$, etc.) of thermal water samples is reported in [13]; observed differences could be attributed to the exploit of different water bearing strata.

Table 4 reports the contents of ${ }^{222} \mathrm{Rn}$ and ${ }^{226} \mathrm{Ra}$ in the water samples 
Table 4: ${ }^{222} \mathrm{Rn}$ and ${ }^{226} \mathrm{Ra}$ content in the 25 water samples collected during the $1^{\text {st }}$ and $2^{\text {nd }}$ sampling (6 months later) period.

\begin{tabular}{|c|c|c|c|c|c|c|}
\hline \multirow[b]{2}{*}{ Sample } & \multicolumn{3}{|c|}{$1^{\text {st }}$ sampling June-July 2003} & \multicolumn{3}{|c|}{$2^{\text {nd }}$ sampling Dec. 2003} \\
\hline & $\begin{array}{l}\text { "unsupported" } \\
{ }^{222} \mathrm{Rn} \mathrm{Bq} \mathrm{kg}^{-1}\end{array}$ & $\begin{array}{c}\text { dissolved } \\
{ }^{226} \mathrm{Ra} \mathrm{Bq} \mathrm{kg}^{-1}\end{array}$ & $\begin{array}{c}\text { total }{ }^{226} \mathrm{Ra} \\
\mathrm{Bq} \mathrm{kg}^{-1}\end{array}$ & $\begin{array}{c}\text { dissolved } \\
{ }^{226} \mathrm{Ra} \mathrm{Bq} \mathrm{kg}^{-1}\end{array}$ & $\begin{array}{l}\text { "unsupported" } \\
{ }^{222} \mathrm{Rn} \mathrm{Bq} \mathrm{kg}^{-1}\end{array}$ & $\begin{array}{c}\text { total }{ }^{226} \mathrm{Ra} \\
\mathrm{Bq} \mathrm{kg}^{-1}\end{array}$ \\
\hline C 1 & 6 & 2.1 & 2.1 & n.d. & 74 & 1.8 \\
\hline $\mathrm{C} 2$ & 10 & 1.6 & 1.6 & n.d. & 59 & 2.4 \\
\hline C 3 & 71 & 2.1 & 2.4 & n.d. & 54 & 1.4 \\
\hline $\mathrm{C} 4$ & 43 & 1.3 & 1.1 & n.d. & 51 & 2.8 \\
\hline C 5 & 34 & 2.0 & 1.8 & n.d. & 84 & 1.4 \\
\hline $\mathrm{C} 6$ & 29 & 2.8 & 3.3 & n.d. & 16 & 3.2 \\
\hline C 7 & 169 & 3.5 & 3.9 & n.d. & 33 & 3.8 \\
\hline C 8 & 59 & 4.0 & 3.6 & n.d. & 4 & 7.1 \\
\hline C 9 & 31 & 4.5 & 3.9 & n.d. & 51 & 4.3 \\
\hline C 10 & 47 & 2.7 & 2.5 & n.d. & 21 & 3.8 \\
\hline C 11 & 103 & 1.3 & 1.8 & n.d. & 96 & 1.9 \\
\hline C 12 & 104 & 0.9 & 0.8 & n.d. & 43 & 1.1 \\
\hline C 13 & 141 & 6.2 & 6.2 & n.d. & 181 & 6.4 \\
\hline C 14 & 17 & 1.0 & 1.0 & n.d. & 86 & 1.4 \\
\hline C 15 & 3 & 6.6 & 6.6 & n.d. & 61 & 7.3 \\
\hline C 16 & 70 & 5.7 & 6.5 & n.d. & 97 & 6.7 \\
\hline C 17 & 3 & 5.8 & 5.4 & n.d. & 2 & 6.7 \\
\hline C 18 & 55 & 6.5 & 6.5 & n.d. & 100 & 5.5 \\
\hline C 19 & 72 & 2.5 & 2.2 & n.d. & 13 & 3.3 \\
\hline C 20 & 103 & 2.5 & 2.3 & n.d. & 85 & 3.2 \\
\hline C 21 & 11 & 3.3 & 3.2 & n.d. & 17 & 2.8 \\
\hline C 22 & 0 & 5.6 & 5.6 & n.d. & 9 & 6.3 \\
\hline C 23 & 29 & 3.7 & 3.7 & n.d. & 33 & 6.4 \\
\hline C 24 & 17 & 2.9 & 2.7 & n.d. & 46 & 3.5 \\
\hline C 25 & 97 & 2.8 & 2.5 & n.d. & 124 & 1.8 \\
\hline Mean & 52,9 & 3,4 & 3,3 & & 57,5 & 3,8 \\
\hline Std dev & 45,6 & 1,8 & 1,8 & & 42,6 & 2,1 \\
\hline Min & 0,0 & 0,9 & 0,8 & & 1,5 & 1,1 \\
\hline Max & 169 & 6,6 & 6,6 & & 181 & 7,3 \\
\hline
\end{tabular}

collected during two sampling campaigns (the second campaign performed 6 months after the first one). It must be said that the two campaigns are not completely comparable, owing to maintainance works that occurred in some spa at the sampling points and/or to meteorological changes to which ${ }^{222} \mathrm{Rn}$ is particularly responsive. From the first sampling period, it is evident that ${ }^{226} \mathrm{Ra}$ appears to be present almost totally in soluble form, for this reason the ${ }^{226} \mathrm{Ra}$ analysis in the second one was performed only in the not filtered sample. 


\section{Conclusions}

The shortage of fresh mud from the customary sources can force some spas to use different mud types. Such replacement should be done under the control of the quality of the results obtained from the "maturation" process of the new blend with thermal water.

The presence of ${ }^{226} \mathrm{Ra}$ in the thermal water gradually increases its concentration on the mud. This effect could be more important with time as the dilution with fresh mud becomes more and more problematical. This problem can be approached in two well-balanced ways:

1) searching for a "new" natural product capable to maintain the special characteristic found in the mud after the "maturation" process.

2) using the selective uptake of Ra from thermal water before the mud treatment.

The second approach has also the advantage of a radical elimination of the radiological problems for spa workers.

\section{References}

[1] G. Astolfi, F. Colombara (1990), La geologia dei Colli Euganei, Editoriale Programma, Padova.

[2] A. Dal Prà, R. Sedea, Note di geologia e idrogeologia euganea, Tip. Valentini - Cadoneghe, 1976.

[3] P. Fabbri, S. Trevisani, Geothermics 34 (2005) 617-631.

[4] F. Veniale, A. Bettero, P. Jobstraibizer, M. Setti, Applied Clay Science 36 (2007) 141-147.

[5] L. Galzigna, A. Lalli, C. Moretto, A. Bettero, Phys. Med. Rehabil. Med. Kurotmed. 27 (1995) 189-194.

[6] F. Tateo et al., Applied Clay Science. 44 (2009) 83-94.

[7] P. Jobstraibizer, Miner. Petrogr. Acta. vol. XLII (1999) 317-327.

[8] E. Mameli, U. Carretta, Due secoli di indagini fisiche e chimiche sulle acque minerali ipertermali, sui fanghi e sui gas euganei, Memorie dell'Accademia Patavina di Scienze ed Arti, vol. 66, parte II (1954) pagg. 1-146. 
[9] G. G. Calapaj, D. Ongaro, G. Fis. Sanit. Prot. Radiaz. 16(3) (1972) 131-144.

[10] A. Bertolo, C. Manduchi, "Ambiente Risorse Salute". 106 (1990) 27-30.

[11] L. Doretti, D. Ferrara, G. Barison, R. Gerbasi, G. Battiston, Radiation Protection Dosimetry 45 1/4 (1992) 175-178.

[12] M. Turlon (2002), Definizione chimica e mineralogica dei fanghi termali utilizzati in ventisette stabilimenti del bacino euganeo, tesi di laurea, inedita. Dip. Mineralogia e Petrografia, Università di Padova.

[13] A. Fasson, Radioattività naturale delle acque minerali calde e dei fanghi utilizzati negli stabilimenti termali di Abano e Montegrotto, tesi di laurea, inedita. Dip. Chimica Inorganica, Metallorganica e Analitica, Università di Padova (2004).

[14] C. Cantaluppi, S. Degetto, J. of Anal. \& Environ. Chem.- Annali di Chimica. 93 (2003) 649-657

[15] S. E. Apitz, S. Degetto, C. Cantaluppi, Marine Pollution Bulletin. 58 (2009) 402-414.

[16] Decreto Legislativo 17 marzo 1995 n. 230 e Decreto Legislativo 26 maggio 2000 n. 241. 